\section{Scientists in Pinochet's Chile}

SIR - As scientists working in Chile, we value the concern that Nature has shown for the state of academic life under Chile's dictatorial regime in publishing Simon Litvak's commentary (Nature 306, 11; 1984). We share Litvak's criticism of the ways in which Chilean universities have been abused for the past ten years. Nevertheless, we think that his article does not fully convey the atmosphere in which Chilean scientists have been living.

Litvak writes that "repression has clearly decreased in recent years" and on this basis he draws an optimistic perspective for the future of Chile's universities. Unfortunately he is wrong. Repression in our country and its universities has lately not decreased but rather dramatically increased, as clearly stated in the 1983 United Nations Report on Human Rights. The Catholic Church, through its Vicaria de la Solidaridad, and the widely respected and politically pluralist Chilean Committee for Human Rights concur with this appraisal. Furthermore, the police continue brutalizing students, as acknowledged by the official press, and paramilitary guards are seen at every gate of the Academia Superior de Ciencias Pedagogicas, severed from the University of Chile in 1981.

\begin{tabular}{llclclc}
\hline & \multicolumn{2}{c}{1981} & \multicolumn{2}{c}{1982} & \multicolumn{2}{c}{1983} \\
Political arrests & $(1)$ & 909 & $(1)$ & 1213 & $(1)$ & 3632 \\
& $(2)$ & 967 & $(2)$ & 1789 & $(2)$ & 2824 \\
Internal exile* & $(1)$ & 60 & $(1)$ & 60 & $(1)$ & 98 \\
& $(2)$ & 60 & $(2)$ & 66 & $(2)$ & 48 \\
Torture & & & & & $(1)$ & 60 \\
denunciations & $(2)$ & 68 & $(2)$ & 123 & (2) & 90
\end{tabular}

(1) Catholic Church, Vicaria de la Solidaridad ( 9 months)

(2) Chilean Committee for Human Rights (6 months) Administrative decision, not judicial.

Reported personally to one or both (1) and (2), or the judiciary.

As to the "further sign of improvement" that Litvak sees "in the fact that new university legislation committees are now working with impressive freedom", he might have known that the participants were chosen by the government; we can now inform him that the outcome of their labour is a project that further reduces the already scant academic autonomy of Chilean universities. Actually, even the university authorities, also appointed by the government, opposed the project and it has been shelved. The influential association "Andres Bello", to which university professors and dismissed professors from different Chilean universities are affiliated, states that "the withdrawal of this project ... cannot ... hide its arbitrary generation nor the conceptual errors it contains". In fact the association had provided the conceptual framework required by legislation concerning the universities but its proposals were ignored. A further example of the lack of dialogue between authorities and university people was the public plea signed by hundreds of professors asking for democratization of universities in order to stop their progress- ive deterioration. This plea has not been acknowledged by the military government.

Litvak refers "to the better overall functioning" of the Catholic University and implies that this stems from respect due to the Church and also to the permanence of its president, a retired admiral. He fails to mention that Cardinal Raul Silva had to relinquish his role as chancellor to a vicechancellor who was less outspoken on human rights. He also fails to mention that some influential professors of the Catholic University have contributed to the ideology of the military regime and in particular to its economic policies. For these reasons the Catholic University is indeed a special case and differs from other Chilean universities. Consider, for instance, the case of the University of Chile, which is still the most important. The Association of Professors of its Faculty of Physics and Mathematical Sciences recently said in an open letter to the Minister of Education: "Since the intervention at University of Chile, more than a decade ago, it has suffered unrelenting attacks of a kind unknown in its more than hundred years of life. It [the University of Chile] has been dismembered, turning it from a national university into a local one. For political and/or ideological reasons, many academicians, students and administrative personnel have been persecuted. The university budget has suffered systematic reductions ... The present situation is such that the academic units that form the University of Chile now receive [funds that are] less than half of what they received in 1973.'

We cannot be optimistic while the universities are still under direct military rule. Revival of our universities is difficult to foresee in the general atmosphere in which academic life has taken place in Chile for the past ten years. We hope that these matters will be of concern to scientists and intellectuals everywhere. It is perhaps impossible to quantify the devastating impact on academic life of the take-over of a democracy by a dictatorship but it must be borne in mind by anyone contemplating the future of his own country or the fate of geographically distant societies.

Patricio Cordero, Manuel A.

GarReton, Humberto GianNini,

ALEJANDRO GOIC, LUIS IZQUIERDO, RAMON LATORRE, JOSÉ MINGUELL, Tito UreTa, Francisco F. VAREla, ENNIO A. VIVALDI

The signatories of this letter are all professors of Universidad de Chile, Casilla 653, Santiago, Chile.

SIR - It is extremely sad that the only thing my colleagues seem to have registered is the moderate optimism I used to analyse the current situation and evolution in Chilean universities. My essential aim was to convey the sense of intrinsic perversity I have always felt about the military intervention in Chilean universities. I wrote the article during a 2-month stay in Chile last year, after meeting many colleagues and reading a considerable amount of material concerning the situation in that country over the past few years. Having lived in Chile for thirty years, visited the country every year for the past 6 years and lived there recently for a whole year (1980-81), I think I have the right to give a personal view of the situation in that country. As I wrote in my article, the situation in the middle of 1983 was quite favourable for positive evolution since the government was in a defensive position due mainly to the poor economic situation and the successful rallies organized by the opposition forces. Unfortunately, the failure of a crucial meeting last September gave new strength to the Pinochet government. As a result the Minister of Education was changed. While the previous incumbent was in charge of the universities a certain degree of demilitarization of these institutions was observed but it is obvious that the "military lobby" in Chilean universities had gathered enough strength to persuade Pinochet to oust her. It is true that those involved in the formulation of a new university law were named by government officials, but I reaffirm my previous assertion that some of the named participants were known for their dissenting views and that the general atmosphere of those discussions was more democratic than expected. The naming of a new Minister of Education coincided with the shelving of these committees, as stated in the letter of Professor Latorre et al. All these unfortunate events, which have slowed the demilitarization process in Chilean universities, happened while my commentary was already in press with Nature.

The human rights situation in Chile is far from acceptable, but to deny a certain degree of improvement in recent years is an act of sheer manicheism or bad faith. The possibility of travel abroad without restrictions and the ability to publish dissenting views in several national or international publications are not enjoyed by intellectuals of other dictatorial states.

Finally, I would like to salute the courage of my distinguished colleagues in signing this letter. If repression in Chile is as harsh as they affirm, we should expect a brutal reaction against them from the Chilean authorities. Let us hope that I am right and that they will be able to continue to play a crucial role in forming a generation that will take into their charge, as we deeply hope, the full democratization of the country.

SimON LiTVAK

Institut Biochimie Cellulaire, Institut Neurochimie du CNRS, 1 Rue Camille Saint Saens, 33077 Bordeaux Cedex, France 